\title{
Karol Dobrzeniecki*
}

\section{THE CONCEPT OF NECESSITY. SOME REMARIKS}

\begin{abstract}
This article aims to provide a general view of the concept of necessity (Latin.: necessitas) and its selected manifestations in the legal sphere (theory and practice).

The author shows that that, at the most general level of considerations, the reaction to an emergency always fits in with a specific philosophy of law that conditions the processes of its creation, application, and validity. The article mentions several variants of answers to the following fundamental questions: Can the law provide for any exceptions? Should the activity - which was to deal with a particular threat - always be grounded in positive law? If not, how should those acts which are outside the scope of this law be treated? These themes have been present in legal thought for centuries. Within individual areas of law, references to necessity and the state of necessity manifest themselves in different ways. Selected institutions of canon, criminal, constitutional, and international law will be provided as examples and discussed later on. As part of a synthetic review of these cases, the similarities and differences in the perception of necessity (state of necessity) and the ways of integrating it into individual legal solutions are presented.
\end{abstract}

\section{Keywords}

necessity - law of necessity - criminal law - constitutional law - public international law

* Associate Professor, Department of Legal Theory, Faculty of Law, Nicolaus Copernicus University, (Torun, Poland), e-mail: karol.dobrzeniecki@umk.pl; ORCID: 0000-0002-6364-9793. 


\section{INTRODUCTION}

The complexity of the relationship between law and politics in a situation which has been caused by a threat, and basic individual or community values, has become a significant and repeatedly discussed issue. Since ancient times numerous references to the idea of necessitas (depending on the context, this term could mean: compulsion, inevitability, indulgence, poverty, plight, lack, hunger, etc.) have appeared in the field of practical philosophy, and have been expressed particularly in concepts such as the law of necessity and the state of necessity. They served to justify or excuse those actions beyond the letter of the law taken by public and private entities in moments of threat. There have been cases of the counteraction of public threats carried out in a legal vacuum or as a contra legem action. When there was no normative 'scenario', the authority holders tried to find legitimacy for such acts in variously interpreted concepts of necessity. Investigation of the essence of the necessity includes, among other things, the issue of whether it is only a circumstance to exclude the unlawfulness of an act, or rather a specific right to act. If one considers the latter, the source of this normativity needs to be clarified - as to whether it is a natural law, the original full sovereignty of a community, or perhaps one of the so-called 'fundamental rights of the state' (according to a popular obsolete theory) $)^{1}$

The indicated concepts have been formed and have evolved within many historical, religious, and political contexts. The materialization of the idea of necessity in the positive law occurred through the borrowings and similarities of canon and civil law, as well as national and international law. Institutions referring to the necessity obtained different forms and applications within particular branches of the law. The present paper aims to follow the directions of the institutionalization of necessity in positive law, where it adopts various shapes and functions, sometimes distant from the original assumptions. Apart from some exceptions, numerous

${ }^{1}$ K. Dobrzeniecki, Prawo wobec sytuacji nadzwyczajnej. Między legalizmem a koniecznościa, Towarzystwo Naukowe Organizacji i Kierownictwa „Dom Organizatora” w Toruniu, 2018, p. 15. 
aspects of the state necessity and law of necessity have not yet been the subject of in-depth analysis in legal science.

\section{THEORIES OF NECESSITY}

In the medieval tradition, invoking necessity served as justification for a transgression done in a particular case. It did not result in the repeal or even suspension of the general norm, but it created an exception relating to specific conditions in which this standard was inapplicable. For example, Thomas Aquinas in Summa Theologix presented the case of a besieged city where a legal order to close the gates after dawn was issued. In his opinion, the norm established in this way is, useful in typical cases and undoubtedly serves to preserve the common good. However, it could lead to closing the gates to a group of significant individuals chased by the enemy, and coming to the city's relief, and so would cause great harm. In such a case, contrary to the letter of the law, the gates should be opened for the benefit of the community, as it should be considered worthy of the goal intended by the legislator. "If there be a sudden danger that does not allow enough time to be able to have recourse to a superior, the very necessity includes an implicit dispensation, since necessity is not subject to the law" (ipsa necessitas dispensationem habet annexam, quia necessitas non subditur legi) ${ }^{2}$.

In modern times, the meaning of necessitas has changed. The law of necessity began to be perceived as the "principle according to which necessity constitutes, so to speak, the ultimate ground and very source of the law" ${ }^{\prime 3}$. In this regard, Niccoló Machiavelli made great contributions by indicating necessitas as the primary substantive right of a sovereign state ${ }^{4}$. Thus, it began to be equated with the state's right to self-preservation ${ }^{5}$.

2 T. Aquinas, Treatise on law, transl. J. B. Atkinson, Hackett Publishing, 2000, p. 61 [question 96, article 6].

${ }^{3}$ G. Agamben, State of exception, trans. K. Attell, The University of Chicago Press, 2006, para 26.

${ }^{4}$ N. Machiavelli, The prince, transl. J. Atkinson, Hackett Publishing 2008.

${ }^{5}$ D. A. Desierto, Necessity and national emergency clauses. Sovereignty in modern treaty interpretation, Brill, 2012, pp. 69-70. 
The maintenance of the state (mantenere lo stato) was for the author of The Prince a goal superior to other goals and values ${ }^{6}$. The interest of the state (raison d'état) has become the highest measure for the evaluation of political action. It gained primacy over all other interests of internal and external entities concerning the state. Another author, Hugo Grotius, thought of necessity as the first right that remained of the old community. He believed that in a state of utmost necessity, the rights derived from the original law of the community reappear in force (for example, the right to use things as if they were common). Such a state is close to the pure state of nature. It is not subject to any human laws that would stand in the way of preserving life ${ }^{7}$. Self-preservation is also the basis of necessity for von Pufendorf. In a life-threatening situation, a person cannot be obliged to refrain from saving himself. "Since man values his preservation so highly, one does not readily presume that any obligation has been imposed on him which should take precedence over his safety" ${ }^{8}$. In the 19th century, the German military doctrine also referred to the idea of necessity. The Kriegsmanier - the proper manner of waging a war determined in detail by the custom - was replaced by the Kriegsräson - references to extraordinary circumstances which take the form of "extreme necessity", providing grounds for departing from the adopted custom 9 . This doctrine stipulated that any norms that would make it technically impossible to win the war would phase out ${ }^{10}$. In his posthumously published work On war (1832), Carl von Clausewitz put forward the thesis that all ways of waging war are justified if they are necessary to successfully end it. He ignored the considerations of proportionality and humanitarianism. Thus, he considered every tactic that led to the achievement of military goals ${ }^{11}$, as appropriate, taking the

${ }^{6}$ Machiavelli, supra note 4, p. 70.

${ }^{7}$ H. Grotius, The rights of war and peace, Book 2, trans. R. Tuck, Liberty Fund, p. $569 \mathrm{ff}$.

${ }^{8}$ S. Pufendorf, On the duty of man and citizen according to natural law, trans. M. Silverthorne, Cambridge University Press, 1991, p. 53.

9 A. W. Heffter, Das europäische Völkerrecht der Gegenwart, Schroeder 1844, para 119.

${ }^{10}$ D. Luban, Military necessity and the cultures of military law, "Leiden Journal of International Law" 2013, vol. XXVI, p. 341.

${ }^{11}$ C. von Clausewitz, On war, transl. M. Howard, P. Paret, Oxford University Press, 2007, pp. 31-44; S. Horton, Military necessity, torture, and the criminality of lawyers, in: 
position that legal idealism cannot be combined with the realism of war. The Prussian maxim: Kriegsräson geht vor Kriegsmanier was understood as meaning that the laws of war phase out in cases of extreme necessity. Such a case occurs when only a violation of the laws of war gives the possibility of either getting out of the extreme danger or achieving the goal of the war - defeating the enemy"12.

With the development of constitutionalism in Europe, criticism of the concept of state necessity gradually grew. The law of necessity was initially treated as a second-class law that requires an act of indemnity of Parliament to be valid and was later denied the status of a law at all. The legal positivists argued that the state of necessity does not exclusively create law, but should be regulated by law to limit the risk of abuse and arbitrariness of power. In the modern legal system, a state of emergency was to function like any other activities of state authorities - based on previously issued general regulations applicable after meeting certain abstract conditions. In line with the development of the concept of the rule of law, the formula of constitutionalization and juridification of an emergency has also been developed. In this way, the concept of the state of emergency was established - a regulated (usually on the constitutional level) special, temporary legal regime, serving to avert a public threat, by considering individual rights and principles of proportionality and legalism. Juridization of emergencies corresponded to the assumptions of 19th-century legal positivism. The introduction of a positive legal basis for a special regime foreseen for the time of danger was a retreat from the concept of the non-statutory law of necessity. Thus, the juridization of the state of emergency was an action aimed at the legal and natural concept of the state's inherent right to self-defence. Nonetheless, it was an attempt to waive all the elements of unpredictability and arbitrariness in the actions of the authorities.

W. Kaleck, M. Ratner, T. Singelstein, P. Weiss (eds.), International prosecution of human rights crimes, Springer, 2007, p. 172.

${ }^{12}$ L. Oppenheim, International law. A treatise, vol. II, Longmans, 1905, p. 79. 


\section{INSTITUTIONALIZATION OF NECESSITY}

\section{CANON LAW}

At least since the time of the Venerable Bede (7th - 8th centuries) Anglo-Saxon monk, Benedictine and Doctor of the Church - reference has been made to necessity as a circumstance mitigating the rigours of administering certain sacraments ${ }^{13}$. An important stage of this process was the verbalization of the legal rule in the form of a maxim: necessitas legem non habet, which was included in the canon law collection of 1140, known as the Gracian decree. In this form, it found its way to the decrees of Pope Gregory IX of 1234, which became a classic reference point for the subsequent discussion on different variants to apply this structure in law. In canonical criminal law, the basis of a state of higher necessity is ", an existing conflict of goods protected by law caused by a danger threatening one of them, in which the danger can only be removed by sacrificing another good"14. There must be a proper balance between these goods (saved and consecrated) - the latter cannot be of a higher order than the former. Canon law also developed the principle of subsidiarity. This principle states that: if there is no other way to control the imminent danger, one is allowed to act and sacrifice the legal good. There were two modern codes of canon law. First was Codex Iuris Canonici, Pii X Pontificis Maximi iussu digestus, Benedicti Papae XV auctoritate promulgatus of 1917 and the other was Codex Iuris canonici auctoritate Joannis Pauli PP. The second promulgatus of 1983 provided for limitations when applying the state of higher necessity. Invoking this circumstance is excluded if the act "causes contempt for God, the faith, or the Church"15.

${ }^{13}$ K. Pennington, Innocent III and the ius commune, in: Grundlagen des Rechts: Festschrift für Peter Landau zum 65. Geburtstag, R. Helmholz et al. (eds.), Paderborn, 2000, p. 353 ff.

14 J. Syryjczyk, Stan wyższej konieczności w prawie karnym kanonicznym, „Prawo kanoniczne: kwartalnik prawno-historyczny" 1982, vol. 25, p. 282,

${ }^{15}$ J. Hollweck, Die kirchliche Strafgesetze: zusammengestellt und commentirt, Franz Kirchheim, 1899, p. 82. 


\section{Criminal LaW}

Institutions of self-defence and the state of necessity have been developed within criminal law. Formally prohibited acts (e.g. destroying things) become legal provided that they were committed in extraordinary circumstances ${ }^{16}$. In modern secular criminal law, a state of greater necessity occurs when the removal of a danger threatening a given good is possible only through actions that meet the conditions of prohibited conduct, for example, by destroying someone else's property. The benefits of such an act should outweigh the losses, hence it is sometimes referred to as the justification of lesser evil. The basis of the choice made between the consecrated and the saved good must be justified in the axiology of the given legal order that recognizes such precedence of goods. Protecting the more valuable good is thereby more beneficial, from the perspective of a given order, than strict adherence to the letter of the law. Its creator could not predict all the possible configurations of specific states ${ }^{17}$. The perpetrator of the act also has a limited ability to choose a different course of action. This is accompanied by strong psychological pressure. Usually, the motive of a person acting in a state of greater necessity is self-preservation or a sense of social solidarity. Both in continental law and the common legal culture, legal solutions allow the perpetrator to be released from liability once certain conditions are met ${ }^{18}$.

The object to be saved may be tangible (e.g. property) or intangible (e.g. freedom). The source of danger is anything, not necessarily manmade. Depending on the solution adopted under a specific legal system, the normative premises for the emergence of a state of higher necessity may vary in shape, i.e. the scope, nature, and proportion of goods or interests remaining in conflict; the source and type of the imminent danger and the appropriate moment for its assessment. The legal consequences

${ }^{16} \mathrm{~K}$. Ghanayim, Excused necessity in western legal philosophy, "Canadian Journal of Law and Jurisprudence" 2006, no.1, p. 34.

$17 \mathrm{~J}$. Blomsma, Mens rea and defences in European criminal law, Intersentia, 2012, p. 371.

${ }^{18}$ M. Gur-Arye, Should the criminal law distinguish between necessity as a justification and necessity as an excuse?, "The Law Quarterly Review" 1986, vol. CII, p. 71-75; A. Brudner, A theory of necessity, "Oxford Journal of Legal Studies" 1987, no. 3, pp. 341-352. 
of applying this institution and crossing its boundaries may be different. In some jurisdictions, the effect of acting in a state of greater necessity will be the exclusion of illegality, whereas, in other jurisdictions, it could be only the release from punishment.

The ratio of the state of higher necessity - as an institution of criminal law - is the protection of legal goods, both individual and social, against the dangers that directly threaten them, but remains within a defined object and subject scale. There are no grounds for invoking the state of higher necessity in the event of a common danger, which applies equally to an undefined group of people or property of considerable size. This extended scale of danger, in which the institutions of criminal law cease to function, constitutes the limit beyond which the concept of necessity acquires a constitutional dimension. Some elements of the normative and theoretical structures of the criminal law have been used to create the concept of a state necessity. In liberal doctrines, the necessary defence is perceived as a kind of inherent right of a sovereign individual to protect his or her goods against unlawful attacks by others. In this approach, it excludes collective and social goods which the state authorities are to protect. Some authors call for granting an individual the right to resist an assault only when there is a lack of an alternative way of avoiding the threat to a specific good ${ }^{19}$. Such a non-self-explanatory approach to necessary defence was also used within the framework of the construction of state necessity. One of the common points of the scientific agenda of criminal and constitutional law is the issue of recognizing higher necessity as a potential source of legitimacy for the activities of persons holding public functions ${ }^{20}$.

\section{Constitutional LaW}

At present, the typical consequence of an emergency for the modern liberal state is the application of the legal norms provided for such circumstance, laid down in the Constitution or Legal Act. They cover various public

19 A. Zoll, W. Wróbel, Polskie prawo karne. Część ogólna, ZNAK, 2010, p. 346.

${ }^{20}$ Dobrzeniecki, supra note 1, p. 288. 
threats and define the manner of the planned use of the state apparatus to deflect the danger. Consequently, a state of emergency is formed and is characterized by an extraordinary and transitional legal status. Its official introduction takes place following the fulfilment of certain formal conditions. The law determines how the normal functioning of the state apparatus is changed and determines the relationship between citizens and the state. In the period of challenging the absolute power of the ancien régime, the juridization and positivization of the law of the state of emergency were carried out at the level of constitutional or statutory acts. The first constitutional law directly suspending constitutional regulations was the French constitution of 1799. The institution of état de siège sanctioned the transfer of all competencies of civilian authorities to a military commander ${ }^{21}$. The scope of application of the above-mentioned institution has gradually expanded - it has ceased to be limited to an external threat but has turned into a fictional state of siege having various uses.

Against the background of the solutions typical for Western countries, the original systemic solution based on the idea of necessity is British martial law. It derives from the common law tradition and constitutes a manifestation of the exercise of the state's right to self-defence. A characteristic feature of martial law is the lack of statutory codification, its essence being the army taking over rule in a specific area. The genesis of this solution dates back to the times of state monarchy. The announcement of martial law is of a declarative nature, and the obligation to maintain public order has arisen already at the time of the necessity to apply emergency measures. To the extent that it is consistent with the English constitution, martial law is an application of the common law principle stating that the measures necessary to preserve the state and stand up to the enemy are justified ${ }^{22}$. Until the mid-19th century, the popular view was that martial law was not subject to legal review. Later it was found that the prerogative constituting the basis for declaring martial law

${ }^{21}$ W. Feldman, Theories of emergency powers. A comparative analysis of American martial law and the French state of siege, "Cornell International Law Journal" 2005, vol. XXXVIII, no.3, p. 1024.

${ }^{22} \mathrm{Ch}$. Fairman, The law of martial rule and the national emergency, "Harvard Law Review" 1942, vol. LV, no.8, p. 1259. 
could not be exercised arbitrarily. While officials and military staff may use their powers to defend the constitution, even against the law, they must justify their proceedings in court once the danger is over. They should show that there is an immediate emergency, ascertainable by any responsible person acting reasonably. The legislature had the power to adopt indemnity laws prohibiting the prosecution of persons taking emergency measures during martial law if they were in good faith ${ }^{23}$.

Some other countries adapted this mechanism from England. In the 19th century, the doctrine of martial law was shaped by political practice and jurisprudence in the USA. The ex post ratification mechanism served, on the one hand, to limit abuse of power and, on the other hand, to avoid permanent systemic changes. It had already been recommended by Thomas Jefferson as an extraordinary tool for approving violations of law committed by officials in the conditions of "extreme crises" and "great dangers", the ad hoc use of which, however, would not lead to the formation of a dangerous constitutional convention. In a letter of February 3, 1807, to Governor William Claiborne, he wrote: "On great occasions, every good officer must be ready to put himself/herself at risk by going beyond the strict line of the law, when the public preservation requires it; his/her motives will equal justification, as far as there is any discretion in his/her ultra-legal proceedings and no indulgence of private feelings". In turn, in the correspondence with John Brown of October 27, 1808, he wrote: "There are extreme cases where the laws become inadequate even to be preserved and where the universal resource is a dictator or martial law" ${ }^{24}$

Martial law is a model of an emergency that is rarely used in AngloSaxon countries these days. Martial law was last proclaimed in the Kingdom of Great Britain in 1780, but theoretically, this institution could form the basis of competence for the military authorities to take any action necessary to restore order. Martial law is referred to in the literature as the public law of greater necessity. The necessity is the basis for its establishment, justifies its existence, and determines the scope and degree

${ }^{23}$ K. Prokop, Modele stanu nadzwyczajnego, Wydawnictwo Temida 2, 2012, pp. 117-121.

${ }^{24} \mathrm{H}$. A. Washington (ed.), The writings of Thomas Jefferson, vol. V, Being his autobiography, correspondence, reports, messages, addresses, and other writings, official and private, John C. Riker, 1854, pp. 40-41, 378-380. 
of its application ${ }^{25}$. According to Carl Friedrich, the concept of martial rule becomes understandable only when it is referred to the rule of law, which it replaces. The visible evidence that such a situation must take place is a state of affairs which makes it impossible for the courts to continue performing their regular functions (the courts are closed) ${ }^{26}$. The US Supreme Court has ruled on this matter several times. The definition was included in the judgment of 1875. "Martial law is the law of military necessity in the actual presence of war. It is administered by the general of the army and is, in fact, his/her will. Of necessity it is arbitrary, but it must be obeyed"27. The phenomenon of necessity is well known to tradition. However, contemporary legal culture is not able to discharge it. In the historical perspective, one should not exclude the case where a state - also a democratic state - that found itself in an extreme position considered the idea of necessity as the primary source of its emergency powers. It is usually assumed that the effect of the non-statutory law of necessity is the suspension of the Constitution and authorization of the government to act freely or even to take actions going beyond the positive law. Cases of special threats are treated by governments as exceptions beyond the legal order. The necessities of political life persuade them to withdraw from legal and sometimes moral bans. The analysis of such cases is possible from the meta-legal aspect, while the legal sanctioning of such activities of the authorities can be done ex post. In general, arguments referring to necessitas are used to justify the deviation from the letter of the law in the name of higher values and the conditions of a serious conflict of legal interests. The nature of this deviation varies depending on the surface. Respecting of extremely unfair law cannot be justified by moral necessity.

Another case is a deviation caused by the situational inapplicability of thelaw, by pressing lack of time, or by the irrationality of legal solutions in the emergency. The exclusion of proper functioning of the legal norms may occur as a result of an extreme threat to the fundamental principles of a particular legal order. Despite significant differences between concepts

${ }^{25}$ F. B.Wiener, A practical manual of martial law, Military Service Publishing, 1940, p. 16.

${ }^{26}$ C. J. Friedrich, Constitutional government and democracy. Theory and practice in Europe and America, Ginn and Companym 1946, p. 239.

27 United States v. Diekelman, 92 U.S. 520 (1875), „United States Reports” 1875, vol. XCII, p. 526. 
of necessity, they share the occurrence of a critical situation, when the survival or annihilation of the highest good depends on the decision taken. The practical importance of the argument regarding necessity in modern times has been significantly reduced. Necessitas ceased to be an independent source of normativity while becoming a dependent, valuable term of the written law or the premise for the legal norm application. The problem of the legitimization of actions taken by a public authority during a time of emergency occurs within the constitutional law. An answer must be provided to the question as to whether these actions should always be based exclusively on the positive law or, at least in some cases, whether they could derive from the situational necessity. State necessity means that beyond the provisions of the Constitution or against it, in an extreme and unforeseen case, any state authority has the power to act do what the situation requires for saving the state. In most contemporary legal systems, the law of state necessity is mostly sui generis, unwritten, non-constitutional, and non-statutory law. Despite the above, the issue of necessity has a raison d'etre in every legal order. In any case, the existence of circumstances unforeseen by the constitutional legislator cannot be excluded. The dynamics of the growth of accidents sometimes makes it impossible to remove the legal gap by conventional methods. Then, law entities face the dilemma of whether to act following the letter of the law or to act primarily in favour of the most important goods and interests, which this law is supposed to protect. The justification of the necessity for public entities to deal with extraordinary threats is a particularly controversial practice from the perspective of the rule of law. Such a case is a vivid departure from the doctrine of legalism. The doctrine of state necessity is quite the opposite of the concept of comprehensive and detailed regulation of the state of emergency at a constitutional and legislative level $^{28}$.

\section{Public International LaW}

In the 19th century, the doctrine of international law and international relations searched for conceptual categories that would be unable to

${ }^{28}$ Dobrzeniecki, supra note 1, p. 291. 
rationally justify the practice of the conduct of a state towards other states in crises. The perception of necessity evolved from a purely political justification for the use of force, to a political and legal construct, the use of which was subject to gradual juridization. The necessity was inscribed in various ways into individual institutions of international law and the standards of its application. In addition to the necessity (or Fr. nécessité), there was the concept of the right to self-preservation, self-help, or the so-called necessity of defence.

The general description of the state of necessity in the context of the law of the international responsibility of the state was outlined at the beginning of the 20th century by Lassa Oppenheim, who is considered to be the father of the modern science of international law. In his view, if the existence or necessary development of a state was in inevitable conflict with its treaty obligations, the latter must yield. Self-preservation and development corresponding to the size and necessary needs of the nation are the basic duty of every state ${ }^{29}$.

The need to clarify and modernize the doctrine of necessity was one of the reasons for initiating work on the codification of the law on the international responsibility of the state, within the League of Nations, and later the United Nations ${ }^{30}$. In the interwar period, as in the previous period, necessity was still treated as an argument originating from the state's original, natural right to self-preservation. The condition for the emergence of a state of higher necessity was considered to be the reality and urgency of the imminent danger. Thus, this concept was subsidiary when the imminent danger could not be reversed through the use of other means, which were ordinary, and legal under international law.

After the Second World War, voices were calling for the complete removal of the concept of necessity from modern international law. The controversy of the doctrine behind it, and difficulties in establishing its status and defining the framework of the possible application, were pointed out. The prevailing opinion, however, was that the elimination of the institution of necessity would lead, at best, to its revival, if necessary, in a different form, using other legal instruments. The International Law

${ }^{29}$ Oppenheim, supra note 12, vol. I, p. 550.

30 S. P. Jagota, State responsibility: circumstances precluding wrongfulness, "Netherlands Yearbook of International Law" 1985, vol. XVI, pp. 250-255. 
Commission (ILC) finally recognized the importance of the practice formed over the years and the achievements of extensive jurisprudence, including references to necessity ${ }^{31}$. In the post-war period, the legal thinking about understanding international legal necessity was an argument in favour of the state taking deliberate actions (or omissions), contrary to its international obligation, in the face of the threat to its basic interests, and not, as it was assumed earlier, the threat to the state itself ${ }^{32}$. Currently, the dominant belief is that acting in conditions of necessity relieves one from the accusation of unlawfulness, but it is not the exercise of the right of the state ${ }^{33}$.

The ILC Draft Articles on Responsibility of States for Internationally Wrongful Acts were concluded at the beginning of the 21st century ${ }^{34}$. The circumstances excluding the unlawfulness of state actions include selfdefence, acting under force majeure [Fr. force majeure], action taken under pressure to save human life (distress) and a state of necessity. In each of the cases described in this way, there are elements characteristic of the idea of necessity, in particular the element of extraordinary threat, the extraordinary situation of the state or its representative, and withdrawal from strict adherence to positive law. In terms of positive law, there are significant differences between these concepts.

Codified in Art. 25 of [the Articles], a necessity in the strict sense is understood by contemporary international law as a factual state in which the unlawfulness of an act of a state is excluded provided that the action taken - inconsistent with the content of an international obligation - is the only way to protect the fundamental interest of the state against serious, direct, and imminent danger? These conditions have to be met cumulatively and their assessment is not solely at the discretion of the state. Deciding what is and what is not a 'basic interest' should be made

${ }^{31}$ L. May, War crimes and just War, Cambridge University Press, 2007, p. 206.

32 J. Crawford, Second report on state responsibility, UN Doc A/CN.4/498 1999, para 278, p. 69.

${ }^{33}$ G. Schwarzenberger, Fundamental principles of international law, "Collected Courses of the Hague Academy of International Law" 1955, vol. LXXXVII, p. 343.

${ }^{34}$ Draft Articles on Responsibility of States for Internationally Wrongful Acts, with Commentaries, "Yearbook of the International Law Commission” 2001, vol. II, part. II, New York 2007. 
following the principle of good faith and within the consensus of the international community, referred to as opinio necessitatis ${ }^{35}$.

The essential interest in its original and most obvious sense was intrinsically related to the question of the existence of the state. If the very existence of the state would be jeopardized if it complied with a specific international obligation, then such compliance would be considered self-destructive. Nowadays understanding the 'basic interest' extends to serious economic crises, issues of protecting the ecological interests of the state and the safety of its citizens, and even the interest of the international community as a whole.

\section{CONCLUSIONS}

The development of the doctrine of necessity over time was parallel to finding applications for necessity as a constituent element of legal instances in particular types and branches of the law. Its evolution proceeded from necessity as an exception applicable to religious rules and church practices to the principle of secular private and public law ${ }^{36}$.

In the classical approach, necessity was a kind of dispensation from the application of human and divine law in specific conditions, i.e. when the goal of a specific legal regulation, which is to focus on the good of man, ceased to exist (salus hominem). In this approach, necessity softens the rigours of the law in the spirit of the principle of summum ius, summa iniuria, but did not undermine its validity. From Grotius comes the tradition of perceiving necessitas as a special subjective right. The law of necessity is part of the natural right of the state to self-preservation. A similar approach is to place necessity outside the legal sphere, within political morality. In other words, the validity of legal norms is negated owing to necessity, since legal order assumes the existence of a normal situation.

35 S. Heathcote, Circumstances precluding wrongfulness in the ILC Articles on State Responsibility. Necessity, in: J Crawford, A. Pellet, S. Olleson et al. (eds), The Law of international responsibility, Oxford University Press, 2010., p. 497.

36 Pennington, supra note 13, p. 353. 
Analyzing the history of theories and doctrines within which the concept of necessity functioned, and also the chronology of formulating its successive versions and varieties, one can risk the statement that this idea has penetrated from the area of private law to criminal and constitutional law, and then from the domain of domestic law to public international law ${ }^{37}$.

At the same time, it was gradually institutionalized, becoming on a different scale and in different ways a part of the applicable law.

37 A. J. Poblador, The defense of necessity in international law, "Philippine Law Journal" 1982, vol. LVII, p. 353-359. 